\title{
KRITERIA PEMILIHAN JENIS KAYU DALAM PEMBUATAN KAPAL WISATA BERDASARKAN PENGETAHUAN MASYARAKAT KELURAHAN TUKTUK SIADONG KABUPATEN SAMOSIR PROVINSI SUMATERA UTARA
}

\section{(The Selection Wood Criteria in Manufacturing of Tour Ship Based on Public Knowledge in Tuktuk Siadong Village Samosir Regency North Sumatera Province)}

\author{
Dina Taruli Gultom ${ }^{1}$, Evi Sribudiani ${ }^{2}$, Sonia Somadona ${ }^{2}$ \\ ${ }^{1}$ Jurusan Kehutanan, Fakultas Pertanian Universitas Riau \\ ${ }^{2}$ Staff Pengajar ${ }^{1}$ Jurusan Kehutanan, Fakultas Pertanian Universitas Riau
}

Jln. Kampus Bina Widya KM. 12,5, Simpang Baru, Kec. Tampan, Kota Pekanbaru, Riau 28293

E-mail: dinataruligultom@gmail.com, sribudiani_unri@yahoo.co.iddan sonia_hut@yahoo.co.id

Diterima: 31 Januari 2020, Direvisi: 10 Februari 2020, Disetujui: 20 Maret 2020

DOI: https://doi.org/10.31849/forestra

\section{ABSTRACT}

Forest has an important part in producing a thing which wood or non-timber and environmental services as a buffer zone for living things. Wood is widely used as carpentry wood, wood tools (furniture), building wood (construction), one of which is in shipbuilding. One of them is a tour ship in Tuktuk Siadong area which is a means of transportation provided by private companies as a special means of transportation for tourists. The purpose of this study was to identify the types and criteria of wood used in the manufacture of tour ship based on public knowledge in Tuktuk Siadong Village, Samosir Regency, North Sumatra Province. This research used a survey and sampling method that was determined purposively. Based on the results of interviews conducted priority wood types used by the community as raw material for making tour ship are johar wood (Cassia seamea) and surian wood (Toona sureni). While alternative wood types used are balau wood (Hopea celebica), kempas wood (Koompassia malaccensis) and nangka wood (Artocarpus heterophyllus). The criteria for raw materials for making a tourist ships are having a tree height $>20 \mathrm{~m}$, tree diameter $>50 \mathrm{~cm}$, wood length $>18 \mathrm{~m}$ with a level of straightness $\geq 80 \%$.

Keywords: Tour ship, wood, wood type

\section{ABSTRAK}

Hutan berperan penting dalam menghasilkan produksi barang baik kayu maupun non kayu dan jasa lingkungan sebagai kawasan penyangga kehidupan bagi makhluk hidup. Penggunaan kayu banyak dimanfaatkan sebagai kayu pertukangan, kayu bangunan (kontruksi) seperti dalam pembuatan kapal. Salah satunya ialah kapal wisata yang merupakan sarana transportasi yang disediakan oleh perusahaan swasta sebagai sarana transportasi khusus bagi wisatawan yang ingin berkunjung atau melakukan wisata. Tujuan penelitian ini untuk mengidentifikasi jenis dan kriteria kayu yang digunakan dalam pembuatan kapal wisata berdasarkan pengetahuan masyarakat Kelurahan Tuktuk Siadong Kabupaten Samosir Provinsi Sumatera Utara. Penelitian dilakukan dengan menggunakan metode survei dan 
pengambilan sampel ditentukan secara purposive. Berdasarkan hasil wawancara yang dilakukan jenis kayu yang menjadi prioritas yang digunakan masyarakat sebagai bahan baku pembuatan kapal wisata adalah kayu johar (Cassia seamea) dan kayu surian (Toona sureni). Sedangkan jenis kayu yang menjadi alternatif digunakan adalah kayu balau (Hopea celebica), kayu kempas (Koompassia malaccensis) dan kayu nangka (Artocarpus heterophyllus). Kriteria bahan baku untuk pembuatan kapal wisata ialah memiliki tinggi pohon $>20 \mathrm{~m}$, diameter pohon $>50 \mathrm{~cm}$, panjang kayu $>18 \mathrm{~m}$ dengan tingkat kelurusan $\geq 80 \%$.

Kata Kunci: Kapal wisata, kayu, jenis kayu

\section{PENDAHULUAN}

Hutan sebagai karunia alam dan amanah Tuhan Yang Maha Esa menjadi sumber penghidupan bagi seluruh makhluk hidup di dunia. Hutan menjadi sumber terbesar penyedia kebutuhan hidup manusia. Hutan berperan penting dalam menghasilkan produksi barang baik kayu maupun non kayu dan jasa lingkungan sebagai kawasan penyangga kehidupan bagi makhluk hidup. Kayu adalah hasil hutan dari kekayaan alam, merupakan bahan mentah yang mudah diproses untuk dijadikan barang sesuai kemajuan teknologi. Kayu merupakan bahan kontruksi yang memiliki peranan penting bagi kehidupan manusia. Meningkatnya teknologi dan budaya manusia, keterkaitan antara manusia dengan hasil hutan terutama kayu tidak dapat dihindari lagi. Penggunaan kayu banyak dimanfaatkan sebagai kayu pertukangan, kayu perkakas (meubel), komponen peralatan kesenian, kayu bangunan (kontruksi) salah satunya dalam pembuatan kapal.

Tuktuk Siadong merupakan salah satu kelurahan di Kabupaten Samosir yang menjadi galangan pembuatan kapal wisata. Kapal wisata yang berada di daerah Tuktuk Siadong ini merupakan sarana transportasi yang disediakan oleh perusahaan swasta sebagai sarana transportasi khusus bagi wisatawan yang ingin berkunjung atau melakukan wisata di Kabupaten Samosir.

Tidak semua jenis kayu yang dapat dipergunakan dalam pembuatan kapal, hanya beberapa jenis kayu saja yang diperbolehkan dengan memperhatikan kriteria kayu tersebut. Masyarakat tentunya memerlukan kayu sebagai bahan baku untuk mempertahankan dan membuat kapal wisata (Irawan, 2011).

Bahan baku kayu yang digunakan pada pembuatan kapal wisata ini tidak saja berasal dari lokasi di sekitar galangan, akan tetapi juga berasal dari luar Samosir 
seperti Kalimantan, Aceh, Sibolga dan Sidikkalang. Hal ini disebabkan jumlah kayu yang tersedia di sekitar galangan masih belum mencukupi kebutuhan pembangunan kapal wisata di Tuktuk Siadong. Bahan baku kayu tentunya dapat diperoleh masyarakat dari hutan. Untuk mengantisipasi masalah tersebut terutama bila kayu-kayu yang selama ini digunakan semakin sulit diperoleh, maka perlu dilakukan penelitian dengan judul "Kriteria Pemilihan Jenis Kayu Dalam Pembuatan Kapal Wisata Berdasarkan Pengetahuan Masyarakat Kelurahan Tuktuk Siadong Kabupaten Samosir Provinsi Sumatera Utara”. Dengan mengetahui jenis kayu tersebut maka upaya pelestarian dapat dilakukan. Kegiatan ini akan berdampak pada ketersediaan kapal wisata yang dibutuhkan.

Tujuan penelitian ini adalah untuk mengidentifikasi jenis dan kriteria kayu yang digunakan dalam pembuatan kapal wisata berdasarkan pengetahuan masyarakat Kelurahan Tuktuk Siadong Kabupaten Samosir Provinsi Sumatera Utara.

\section{METODE PENELITIAN}

Penelitian ini berlokasi di Kelurahan Tuktuk Siadong Kecamatan Simanindo Kabupaten Samosir Provinsi Sumatera Utara. Waktu penelitian dilaksanakan pada bulan Februari 2019. Alat yang digunakan dalam penelitian ini adalah alat tulis, perekam, kamera (alat dokumentasi), dan laptop untuk pengolahan data. Bahan yang digunakan berupa kuesioner. Penelitian ini dilakukan dengan menggunakan metode survei yaitu metode yang bertujuan untuk mengumpulkan data dari sejumlah variabel pada suatu kelompok masyarakat melalui wawancara langsung dan berpedoman pada pertanyaan yang telah disediakan sebelumnya. Sampel yang dipilih ditentukan secara purposive, artinya peneliti mewawancarai langsung orang yang dianggap paham dengan jenis dan kriteria kayu yang digunakan dalam pembuatan kapal wisata. Berdasarkan observasi yang dilakukan, terdapat 3 perusahaan yang memiliki kapal wisata yaitu Samosir Cottage, Toledo Inn dan Silintong Hotel dimana dari ketiga perusahaan ini masing-masing memiliki pegawai yang berprofesi sebagai supir kapal serta berpengalaman dalam membuat kapal wisata. Dalam pembuatan kapal 
wisata, pegawai tersebut tidak lepas dari bantuan tukang bangunan yang membantu proses pembuatan kapal. Di Kelurahan Tuktuk Siadong terdapat 2 orang tukang bangunan yang berpengalaman dalam pembuatan kapal wisata. Sehingga dari hasil survei yang telah dilakukan, terdapat 5 orang informan yang diharapkan dapat memberikan informasi sesuai dengan tujuan penelitian.

Pelaksanaan penelitian ini terbagi beberapa teknik antara lain ialah observasi, wawancara dan studi literatur. Data dan informasi yang dikumpulkan merupakan data primer dan data sekunder. Data primer yaitu pengumpulan data yang dilakukan dengan wawancara langsung kepada responden dengan menggunakan daftar pertanyaan dan pengamatan langsung terhadap struktur anatomi kayu, data tersebut mengenai jenis kayu dan kriteria kayu. Sedangkan data sekunder diperoleh dari studi literatur yang relevan dengan objek kajian yang menunjang penelitian.

Analisis data yang digunakan dalam penelitian ini adalah analis deskriptif kualitatif. Berikut aktivitas dalam analisis data kualitatif yaitu:
1. Reduksi data ialah mereduksi data yang berarti merangkum, memilih halhal yang pokok, memfokuskan pada hal-hal yang penting.

2. Data display (penyajian data) yang dilakukan dalam bentuk uraian singkat, bagan, hubungan antar kategori, flowchart dan sejenisnya. Penyajian data yang paling sering digunakan dalam penelitian ini adalah dengan teks yang bersifat naratif (Sugiyono, 2007).

\section{HASIL DAN PEMBAHASAN}

\section{Kondisi Umum Lokasi Penelitian}

Luas wilayah Kabupaten Samosir yaitu $2.069,05 \mathrm{~km}^{2}$ yang terdiri dari luas daratan seluas 1.444,25 $\mathrm{km}^{2}$ dan luas danau seluas $624,80 \mathrm{~km}^{2}$. Kabupaten Samosir terletak pada wilayah dataran tinggi dengan ketinggian antara 904-2.157 mdpl dengan topografi dan kontur tanah yang beranekaragam yaitu: datar, landai, miring dan terjal. Struktur tanahnya labil dan berada pada wilayah gempa tektonik dan vulkanik. Kabupaten Samosir terdiri dari sembilan kecamatan, dimana enam kecamatan diantaranya berada pada di Pulau Samosir yaitu: Kecamatan 
Simanindo, Kecamatan Pangururan,

Kecamatan Palipi, Kecamatan Nainggolan,

Kecamatan Onan Runggu dan Kecamatan

Ronggur Ni Huta serta tiga kecamatan berada pada di Pulau Sumatera yaitu: Kecamatan Sitio-tio, Kecamatan Harian dan Kecamatan Sianjur Mula-mula.

Luas wilayah Kecamatan Simanindo adalah 198,20 $\mathrm{km}^{2}$, dengan luas yang demikian terdapat banyak objek wisata yang menjadi sentra pariwisata Kabupaten Samosir. Salah satu diantaranya adalah yang terdapat di Kelurahan Tuktuk Siadong. Perkembangan Tuktuk Siadong terjadi sedemikian rupa diakibatkan oleh semakin dikenalnya Tuktuk Siadong sebagai salah satu daerah tujuan wisata di Sumatera Utara.

\section{Deskripsi Responden}

Responden adalah orang yang dimintai jawaban atau tanggapan maupun pertanyaan yang diajukan. Deskripsi responden berkaitan dengan identitas responden seperti nama, usia dan latar belakang pekerjaan. Sampel yang dijadikan sebagai responden adalah orang yang mengetahui dan dapat menjelaskan tentang jenis dan kriteria kayu yang digunakan dalam pembuatan kapal wisata. Identitas responden dalam penelitian ini dapat dilihat pada tabel 1 .

Tabel 1. Identitas Responden

\begin{tabular}{|c|c|c|}
\hline Nama & Umur & Pekerjaan \\
\hline Tahi Silalahi & 56 tahun & $\begin{array}{l}\text { Pembuat } \\
\text { kapal }\end{array}$ \\
\hline Radot Rumahorbo & 54 tahun & $\begin{array}{l}\text { Pembuat } \\
\text { kapal }\end{array}$ \\
\hline Suandi Simbolon & 48 tahun & Supir kapal \\
\hline $\begin{array}{l}\text { Roganda } \\
\text { Manurung }\end{array}$ & 45 tahun & Supir kapal \\
\hline Indra Sinaga & 42 tahun & Supir kapal \\
\hline
\end{tabular}

Penentuan responden dipilih secara cermat yang benar-benar mengetahui dan terkait dengan permasalahan dari objek penelitian. Responden pada penelitian ini baik pembuat kapal maupun supir kapal memiliki peran penting dalam proses penentuan dan pengambilan keputusan dari jenis dan kriteria kayu yang digunakan sebagai bahan baku pembuatan kapal.

\section{Pengetahuan Masyarakat Tentang} Kapal Wisata

Berdasarkan hasil wawancara yang dilakukan, responden menyatakan bahwa kapal wisata ini menjadi aset untuk semakin meningkatkan kunjungan wisatawan ke Danau Toba. Secara singkat dapat dikatakan bahwa kapal wisata ini digunakan untuk aktivitas wisata yang melakukan perjalanan ke beberapa 
destinasi dimana para penumpang tersebut dapat turun untuk mengunjungi atraksi wisata yang ada. Dengan adanya kapal wisata ini, wisatawan akan semakin mudah berkeliling Danau Toba dan Pulau Samosir. Kapal dengan berbahan dasar kayu ini dibangun dan didesain berdasarkan tradisi, pengetahuan serta pengalaman si pembuatnya. Kapal dengan perahu panjang (long boat) $\pm 18 \mathrm{~m}$ dan lebar $\pm 6 \mathrm{~m}$ ini mampu menampung penumpang sebanyak \pm 40 orang.

Pengetahuan dan keterampilan dalam pembuatan kapal wisata Tuktuk Siadong diperoleh secara turun temurun berdasarkan pengalaman si pembuat sebelumnya. Dari wawancara yang telah dilakukan, pembuatan kapal wisata ini biasanya memakan waktu 5-6 bulan dengan jumlah pekerja 6-8 orang. Desain dan konstruksi merupakan hal yang sangat mendasar dalam rencana pembuatan kapal.

Dalam pembuatan kapal harus memperhatikan ketahanan, kestabilan dan kelayakan kapal beroperasi. Untuk memperpanjang usia pemakaian kapal, maka perlu dilakukan upaya perawatan. Dalam menjaga kapal agar tetap awet dan lebih tahan lama dilakukan dengan cara tersendiri yang biasa dilakukan untuk memperpanjang masa pakai kapal (Aji, 2000).

Dari hasil wawancara yang telah dilakukan, masyarakat melakukan perawatan secara berkala yang dilakukan sekali dalam 2 minggu. Perawatan yang dilakukan masih secara tradisional meliputi:

1. Membersihkan kapal dari sisa air seperti lumut dan binatang air yang menempel pada badan kapal. Proses ini dilakukan dengan menyikat bagian kapal yang terkena air.

2. Pemakalan bagian papan kapal. Perawatan kapal dengan cara pemakalan ini dilakukan apabila terdapat celah pada lantai dasar dan lambung kapal. Proses pakal ini dilakukan dengan menjejalkan dempul damar dan tali goni pada celah antar papan.

3. Mengecat badan kapal. Proses pengecatan kapal ini dilakukan untuk mencegah adanya hewan air yang masuk ke dalam pori-pori kapal

4. Penggantian bagian kapal yang rusak. Penggantian bagian kapal yang rusak dilakukan apabila papan penyusun 
kapal mengalami kerusakan sehingga perlu diganti. Proses ini dilakukan di daratan dengan cara pemasangan yang sama pada saat pembuatan kapal. Khusus proses ini biasanya dilakukan saat perenovasian kapal dimana kapal sudah mencapai pemakaian 15-20 tahun.

\section{Pengetahuan Masyarakat Tentang} Pemilihan Jenis Kayu Sebagai

\section{Bahan}

\section{Baku Pembuatan Kapal Wisata}

Jenis kayu yang dibutuhkan sebagai bahan baku untuk membuat kapal wisata ini diambil dari hutan alam yang terdapat di Kabupaten Samosir. Pemakaian jenis kayu berdasarkan pada kebiasaan pembuat kapal dalam mengkonstruksi kapal buatannya. Pengetahuan yang didapatkan hanya berasal dari warisan para pendahulunya sehingga jenis kayu yang digunakan dari tahun ke tahun relatif sama. Dalam memilih bahan baku untuk pembuatan kapal memiliki kriteria tersendiri. Kriteria kayu yang digunakan untuk pembuatan kapal antara lainnya yaitu kayu harus kuat, ringan, tidak mudah pecah, lurus serta tahan terhadap serangan organisme perusak kayu khususnya binatang laut (Lanoeroe, Kesaulija dan Rahawarin, 2005) Jenis-jenis kayu pada pembuatan kapal wisata menurut responden dilihat pada tabel 2 .

Tabel 2. Jenis kayu menurut responden

\begin{tabular}{ll}
\hline \multicolumn{1}{c}{ Nama } & \multicolumn{1}{c}{ Jenis kayu } \\
\hline Tahi Silalahi & $\begin{array}{l}\text { Johar, Surian, Balau, } \\
\text { Kempas }\end{array}$ \\
Radot & Johar, Surian, Kempas \\
Rumahorbo & \\
Suandi Simbolon & Johar, Surian, Nangka \\
Roganda & Johar, Surian, Balau, \\
Manurung & Kempas \\
Indra Sinaga & Johar, Surian, Nangka \\
\hline
\end{tabular}

Dari hasil wawancara pada tabel 2, seluruh responden cenderung hanya menggunakan 2 jenis kayu sebagai prioritas utama yang digunakan dalam pembuatan kapal wisata yaitu kayu johar dan kayu surian. Hal ini dikarenakan bahan baku terdapat di kawasan hutan alam Samosir sehingga memudahkan masyarakat untuk lebih menghemat biaya dan waktu. Hal yang membedakan persepsi pada seluruh reponden ini adalah pada pemilihan jenis kayu alternatif yang digunakan. Untuk penggunaan kayu balau biasanya digunakan apabila kayu prioritas utama sulit ditemukan. Pihak perusahaan menggunakan kayu balau dengan mendatangkannya dari luar Samosir seperti Kalimantan, Aceh, Sibolga dan Sidikkalang. Begitupun untuk jenis kayu kempas dan kayu nangka, kedua jenis kayu ini digunakan apabila jenis kayu prioritas utama sulit ditemukan 
terkhusus kayu surian. Perolehan kedua jenis kayu ini tergolong mudah karena bisa ditemukan disekitar penggalangan atau lingkungan tempat tinggal masyarakat. Kedua jenis kayu ini biasanya digunakan hanya pada bagian dek kapal saja. Dalam pembuatan kapal wisata, perusahaan melibatkan masyarakat yang dimulai dari pencarian bahan baku hingga membawanya ke lokasi galangan pembuatan kapal. Dalam proses pembangunannya, tentu tak lepas dari partisipasi masyarakat sekitar, baik dalam bentuk pikiran maupun tenaga yang dibutuhkan. Masyarakat tidak sembarang dalam dalam menentukan jenis kayu yang digunakan untuk setiap konstruksi kapal. Dari wawancara yang telah dilakukan, responden mengatakan bahwa mereka cenderung memilih kayu yang kuat dan awet sehingga kapal bisa bertahan dalam waktu yang lama. Pemilihan jenis kayu ini menjadi dasar masyarakat menggunakan kayu tersebut sebagai prioritas maupun sebagai alternatif. Untuk lebih jelasnya mengenai prioritas dan alternatif kayu yang digunakan pada setiap konstruksi kapal dapat dilihat pada tabel 3 .

Tabel 3. Jenis Kayu Prioritas dan Alternatif Pada Setiap Konstruksi Kapal

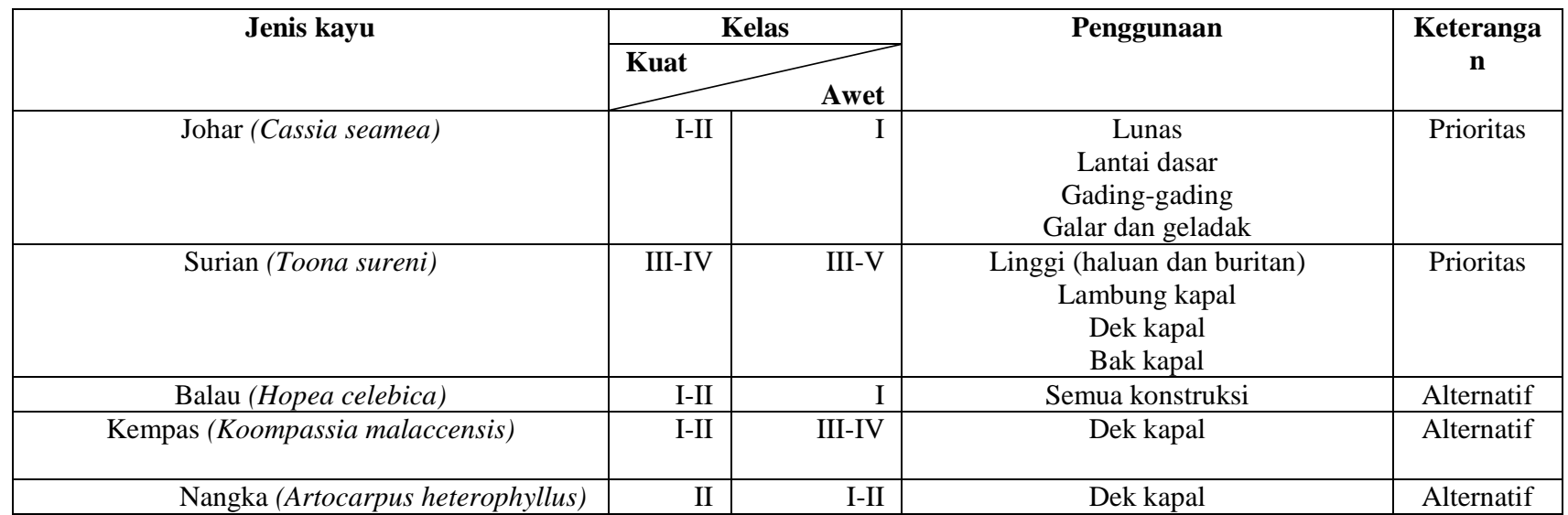

\section{Pengetahuan Masyarakat Tentang} Kriteria Pohon Yang Digunakan Sebagai Bahan Baku Pembuatan Kapal Wisata

Kriteria merupakan ukuran yang menjadi dasar penilaian atau penetapan sesuatu. Bahan baku kapal juga mempunyai kriteria pohon tertentu sebelum diolah atau dibuat menjadi kapal. Kriteria ini bertujuan guna sebagai acuan dalam pembuatan kapal. Dalam pemilihan jenis pohon untuk pembuatan kapal dipilih pohon yang memiliki batang yang 
bebas cabang cukup panjang karena hal ini akan sangat berpengaruh terhadap kekuatan kayu itu sendiri. Dengan penentuan kriteria, kapal dapat berbentuk sesuai fungsi yang digunakan dan dapat memudahkan dalam pengerjaan karena ukurannya telah ditentukan (Lanoeroe, Kesaulija dan Rahawarin, 2005)

Dalam proses pembuatan kapal, perencanaannya dilakukan mengenai panjang lunas, panjang total dan ukuran kapal yang akan dibuat. Namun sebelum itu, perencanaan bahan baku kapal kayu merupakan hal yang sangat penting dilakukan karena akan berdampak pada kemampuan kapal dan berpengaruh terhadap stabilitas kapal saat beroperasi. Dalam pembangunan kapal secara

Tabel 4. Kriteria Bahan Baku Pembuatan Kapal Wisata

\begin{tabular}{lrrrr}
\hline \multirow{2}{*}{ Responden } & \multicolumn{2}{c}{ Kriteria pohon } & \multicolumn{2}{c}{ Kriteria kayu } \\
\cline { 2 - 5 } & $\begin{array}{r}\text { Tinggi pohon } \\
(\mathbf{m})\end{array}$ & $\begin{array}{r}\text { Diameter pohon } \\
(\mathbf{c m})\end{array}$ & $\begin{array}{r}\text { Panjang kayu } \\
(\mathbf{m})\end{array}$ & $\begin{array}{r}\text { Kelurusan kayu (\%) } \\
\text { Tahi Silalahi } \\
\text { Radot Rumahoro }\end{array}$ \\
Suandi Simbolon & $>20$ & $>50$ & $18-20$ & $\geq 80$ \\
Roganda Rumahoro & $>20$ & $>50$ & 20 & $\geq 80$ \\
Indra Sinaga & $>20$ & $>50$ & 18 & $\geq 80$ \\
& $>20$ & $>50$ & 20 & $\geq 80$ \\
\hline
\end{tabular}

Berdasarkan Tabel 4, dapat dilihat bahwa responden umumnya memilih tinggi pohon dengan ukuran di atas $20 \mathrm{~m}$ untuk kriteria kayu yang digunakan sebagai bahan baku pembuatan kapal wisata. Alasan masyarakat memilih tinggi pohon dengan ukuran tersebut dikarenakan mempengaruhi panjang kayu yang akan tradisional, para pengrajin harus menentukan kriteria-kriteria pohon yang diperlukan (Purwanto, 2014).

Dalam pembuatan kapal wisata, masyarakat tidak sembarangan dalam memilih pohon yang digunakan. Kriteria pohon dapat menentukan fungsi dari kapal tersebut. Apabila salah dalam menentukan kriteria pohon, bisa saja kayu yang diolah atau dibentuk tidak sesuai dengan hasil yang diharapkan untuk pembuatan kapal. Untuk lebih jelas mengenai kriteria bahan baku yang digunakan masyarakat sebagai bahan baku kapal wisata dapat dilihat pada tabel 4 . 
Pemilihan kriteria diameter pohon, responden memilih pohon dengan diameter 50-100 cm. Masyarakat mengatakan semakin besar diameter pohonnya maka akan semakin bagus digunakan untuk bahan baku kapal. Alasan masyarakat memilih ukuran diameter tersebut dikarenakan kapal yang dibangun memiliki ukuran yang cukup besar. Bobot yang besar dan berat membuat kapal ini lebih stabil dan tahan terhadap guncangan gelombang sehingga cocok untuk tujuan pelesir meski kecepatan menjadi berkurang (Simarmata, 2018). Semakin besar diameter tengah pohon, maka bangunan kapal/jalur yang dihasilkan akan sulit untuk karam dari guncangan gelombang (Suwardi, 1984).

Tingkat kelurusan kayu dapat mempengaruhi bentuk kapal itu sendiri. Dari hasil wawancara yang telah dilakukan, sebenarnya responden menginginkan tingkat kelurusan yang $100 \%$. Namun karena sangat sulit untuk menemukan kayu yang benar-benar lurus $100 \%$, maka responden memilih tingkat kelurusan minimal $80 \%$ dengan ketentuan kelurusan kayu tersebut layak digunakan sebagai bahan baku pembuatan kapal.
Pada dasarnya bentuk fisik kayu gelondong atau kayu log memang bermacam-macam dan hampir tidak ada yang benar-benar sempurna tingkat kelurusan dan kebulatannya. Ada yang bulatnya tidak beraturan seperti buah belimbing yakni berbentuk bintang dan ada juga yang melengkung (Rimba, 2010).

\section{KESIMPULAN DAN SARAN}

\section{A. Kesimpulan}

Jenis kayu yang menjadi prioritas digunakan masyarakat Kelurahan Tuktuk Siadong Kabupaten Samosir sebagai bahan baku pembuatan kapal wisata adalah kayu johar (Cassia seamea) yang digunakan pada konstruksi lunas, lantai dasar, gadinggading, galar dan geladak kapal, kayu surian (Toona sureni) yang digunakan pada konstruksi linggi (haluan \& buritan), lambung, dek dan bak kapal. Jenis kayu yang menjadi alternatif digunakan adalah kayu balau (Hopea celebica) yang digunakan pada semua bagian konstruksi kapal, kayu kempas

(Koompassia malaccensis) dan kayu nangka (Artocarpus heterophyllus) yang digunakan pada konstruksi dek kapal. Kriteria bahan baku yang digunakan dengan memiliki tinggi pohon $>20 \mathrm{~m}$, diameter pohon $>50 \mathrm{~cm}$, 
panjang kayu >18 m dengan tingkat kelurusan $\geq 80 \%$.

\section{B. Saran}

Diharapkan kepada masyarakat Kelurahan Tuktuk Siadong untuk melakukan penanaman kembali jenis pohon yang menjadi prioritas untuk bahan baku pembuatan kapal wisata setelah melakukan penebangan agar keberadaan pohon tetap lestari.

\section{DAFTAR PUSTAKA}

Aji, C. A. (2000). Pengetahuan Lokal Pembuatan Perahu Tradisional oleh Suku Biak di Kecamatan Warsa Kabupaten Biak Numfor. Universitas Cendrawasih.

Irawan, H. (2011). Usulan Konstruksi Kapal Kayu Tradisional dengan Menggunakan Lambung Laminasi. Universitas Indonesia.

Lanoeroe, S., Kesaulija, E. M. and Rahawarin, Y. Y. (2005). 'Pemanfaatan Jenis Tumbuhan Berkayu sebagai Bahan Baku Perahu Tradisional oleh Suku Yachai di Kabupaten Mappi', 6, pp. 212-216. doi: 10.13057/biodiv/d060315.

Purwanto, Y. (2014). Aspek Keselamatan Ditinjau dari Stabilitas Kapal dan Regulasi pada Kapal Pole and Line di Bitung Sulawesi Utara. Institut Pertanian Bogor.

Rimba (2010). Memahami Cara Memilih
Kayu Gelondong. Available at: http://rimbakita.blogspot.com/2013/01 /23/tips-memilih-kayu-log.html/.

Simarmata (2018). Danau Toba Miliki Kapal Pesiar. Available at: http://harian.analisadaily.com/kesra/ne ws/danau-toba-miliki-kapalpesiar/494804/2018/01/29.

Sugiyono (2007). Statistik untuk Penelitian. Bandung: Penerbit Alfabeta.

Suwardi, M. S. (1984). Pacu Jalur dan Upacara Pelengkapnya. Jakarta: Proyek Media Kebudayaan Jakarta. 